\title{
Use of the effectiveness of cuachalalate from healing plants in Mezquitic, Jalisco
}

\section{Uso de la efectividad de cuachalalate de las plantas curativas en Mezquitic, Jalisco}

GONZÁLEZ-GARCÍA, Arcelia, HERNÁNDEZ-SALAS, Claudia, MARTÍNEZ-ORTIZ, Rosa María and GONZÁLEZ-MARTÍNEZ, Lilia

\begin{abstract}
${ }^{1}$ Universidad Autónoma de Zacatecas-Licenciatura en Químico Farmacéutico Biólogo, Licenciatura en Enfermería UAE. ${ }^{2}$ Unidad Académica de Odontología. Campus UAZ. Siglo XXI Carretera Zacatecas-Km.6 Ejido La Escondida Zacatecas Zac.C.P. 98160
\end{abstract}

ID $1^{\text {st }}$ Author: Arcelia, González-García

ID $1^{\text {st }}$ Author: Claudia, Hernández-Salas

ID $2^{\text {nd }}$ Co-author: Rosa María, Martínez-Ortiz

ID $3^{\text {rd }}$ Co-author: Lilia, González-Martínez

\begin{abstract}
Cuachalalate is (Amphiterigium adstringens )an arboreal species of the low deciduous forest whose bark has been used since pre-Hispanic times in traditional medicine because it is one of the products of greatest demand of Mexican herbalism and the economic importance for the communities that live in this ecosystem in the inifap Since 1989, research has been carried out to improve its management, which currently allows its sustainable and legal use. This study was carried out in Jalisco Zacatecas whose objective was to know the use of the curative plants of cuachalalate with traditional medicine as preventive of a scarring of some of the wounds as well as the most frequently consumed and the results indicate that the main areas or fronts of the cortex are from the State of Jalisco for the human
\end{abstract}

Use of Healing Plants, Medicinal

\begin{abstract}
Resumen
El cuachalalate, (Amphipterigium adstringens), es una especie arbórea de la selva baja caducifolia, cuya corteza se utiliza desde tiempos prehispánicos en la medicina tradicional. Por ser uno de los productos de mayor demanda en la herbolaria mexicana y de importancia económica para las comunidades que viven en este ecosistema, en el INIFAP desde 1989 se han realizado investigaciones para mejorar su manejo lo que permite actualmente su aprovechamiento sustentable y legal. Se llevó acabo este estudio en Mezquitic, Jalisco, cuyo objetivo fue conocer el uso de las plantas curativas del cuachalalate como medicina tradicional, como preventivo de una cicatrización de algunas de las heridas así como también el uso más frecuente de consumo. Resultados indican que las principales áreas oferentes de corteza son el estado de Jalisco en el ser humano.
\end{abstract}

Uso de plantas curativas, Medicinales

Citation: GONZÁLEZ-GARCÍA, Arcelia, HERNÁNDEZ-SALAS, Claudia, MARTÍNEZ-ORTIZ, Rosa María and GONZÁLEZ-MARTÍNEZ, Lilia. Use of the effectiveness of cuachalalate from healing plants in Mezquitic, Jalisco. Journal of Quantitative and Statistical Analysis. 2021. 8-22: 25-30

\footnotetext{
* Correspondence to Author (e-mail: arcelia2009@ live.com.mx)

$\dagger$ Researcher contributing as first author.
} 


\section{Introduction}

Healing plants today have been the traditional alternative medicine, in the effectiveness in the ethnomedicine of Mezquitic, Jalisco, the medicine as an alternative. In line with the prevention, cure and healing, which was carried out by the ethnographic method, to obtain information on perceptions, of the healing plants that today are present in the environment, which are used in traditional medicine, is of great help with an efficiency of consuming them for a health and economic benefit, due to the environment, traditional medicine according to the world health organization (WHO), traditional medicine is a set of knowledge, belief skills, experiences, values in curative preventive medicine as an improvement in the treatment of mental physical illnesses in societies, ethnomedicine refers to the medical study of traditional typical plants, they focus on the interpretation of culture and health, medicinal care processes, healing and health (Williams, 2006) the belief of healing plants for the health of society, making it interdisciplinary.

Traditional medicine has been studied from the medical anthropology that studies the problems of human health and healing systems in their social, cultural and economic contexts; analyzes the mediations that explain the differential ways of falling ill, being cared for and dying among certain individuals and groups, considers the characteristics and peculiarities of the relationships between people and social groups that enable or limit the resolution of their health problems (Freyermuth and Sesia, 2006 , P. According to Aparicio (2004): "five fundamental features define traditional medicines: 1. Validity as ethnomedicine (therapeutic system adapted to a specific sociocultural and geographical environment and context that responds to health needs.

In Mexico, traditional medicine is recognized by the Ministry of Health, the Mexican Institute for the Study of Medicinal Plants and the Commission for the Use and Conservation of Biodiversity, which has a digital Library on medicinal plants. In traditional Mexican medicine, the use of plants is of great importance, for example, it is practiced by its 60 ethnic groups, who use more than 5,000 plants (González-Stuart and Rivera, 2009 in JuárezRosete et al., 2013). In urban areas, traditional medicine is used, mainly through
Herbalism (Osuna et al., 2005). Medicinal plants in Mexico are mostly wild (Osuna et al., 2005), which is related to the local environmental knowledge of the country's ethnic groups and that they are not only collected for internal use, but some species are cultivated for export. Traditional medicine is based on local environmental knowledge, it is adaptive to spatio-temporal contexts and its owners are mainly native peoples. This practice is older than any other therapy: the systematic consumption of plants with medicinal attributes probably dates back to 2 million years in Africa (Chifa, 2010).

At a global level, knowledge, relevance and is considered a priority by institutions such as: International Organization for Intellectual Property, World Health Organization, International Labor Organization and various United Nations dependencies (United Nations Food and Drug Administration Organization). Agriculture, United Nations Educational, Scientific and Cultural Organization; United Nations Environment Program; Commission on Rights At the same time they contribute to the conservation of traditional cultures today in the world and the biodiversity, as part of sustainable development.

Currently, society looks for options for good health and physical and psychological well-being, especially through traditional medicine. It is characterized because every therapeutic act contains a merely empirical part, which is accompanied by a magical-religious intention, medicinal healing plants are characterized by an integral approach to health shows that the human being as a cultural and social being is based on local environmental knowledge, includes botanical, zoological, ecological and technological knowledge (Fagetti, 2011) There is interest in traditional medicine due to the search for alternatives to allopathic medicine to treat diseases with natural and non-synthetic remedies, to be cared for in a friendly way and in a trusting relationship between patient and doctor. Cuachalalate. Amphipterygium adstringens Schiede ex Schlech. (Anacardiaceae) with popular synonymy chalalate, coachalalate, volador, cuachalalá or cuachinala and botanical synonymy Juliania adstringens Schlechter. It is a tree $10 \mathrm{~m}$ high, with a twisted trunk, grayish bark, with scales. 
The leaves on the front are dull green and on the back they are grayish, grouped at the tips of the branches. The flowers are solitary or in clusters. One of the most important uses that cuachalalate has within Traditional Mexican Medicine is the treatment of diseases related to the digestive system, to corroborate this activity (Navarrete in 1998), carried out the corresponding studies to evaluate the gastroprotective effect of the extract of the bark of $\mathrm{A}$. adstringensis in ulcers, as well as the healing, Currently, Traditional Mexican Medicine is recognized as a resource for the preservation of the health of millions of human beings, it is an important part of the worldview of indigenous peoples, representing the knowledge about mother earth and the use of medicinal plants.

This wisdom, day by day, has been acquiring more and more importance, due to its strengthening in order to preserve its identity. Within this plant treasure, is Cuachalalate, which has been widely used in Traditional Medicine as a gastroprotective agent, where the stem is used in the form of an infusion to treat stomach ulcers, this due to the decrease in the secretion of gastric juices. , helping the renewal of the epithelium. Bark for wound healing Previous studies show that the biological activity is due to the presence of triterpenes, such as masticadienonic acid and some of its derivatives.

The tree highlights the importance of this native tree, in Mezquitic Jalisco as, in its use in the alternative that is curative and preventive for health, these plants as well as for digestive problems, as well as the chemical profile to know the secondary metabolites responsible for their biological activity. The uses of cuachalalate the bark of the tree hardens the gums, relieves fires and mouth ulcers, there is also a decrease in urinary discomfort and affections to the kidneys and wound healing, especially in the skin situation, grains or deep wounds, relieves the stomach inflammation, chronic gastritis, gastric ulcers according to a group of scientists from the department of natural products of the Institute of Chemistry, has been investigating that cuachalalate is capable of inoculating human cancer cells in a less toxic way, more effective than drugs conventional anticancer agents. Patricia Bañuelos told us that the pieces of bark from a tree that they brought were "cuachalalá" (known in other places as cuachalalate). It is for medicinal use.
The UNAM Digital Library of Traditional Mexican Medicine states that this vegetable is used to treat ulcers, wounds and gastritis, among other ailments. Being one of the municipalities in which the Wixárika culture is based, the handicrafts made with beads could not be missing in this sample. Necklaces, earrings, rings and keychains with designs of contrasting figures and colors. Trays made with light sabino wood were also offered wixárika cheered the old mansion in downtown Guadalajara with his music that houses the Museum of Popular Arts in Jalisco. In addition to the lack of economic resources to have access to modern medicine, the change in needs and beliefs contribute to the practice and the rise of alternative, traditional medicine remains (Zhang, 2004), such as the preference for treating diabetes with medicinal plants (Warjeet, 2011).

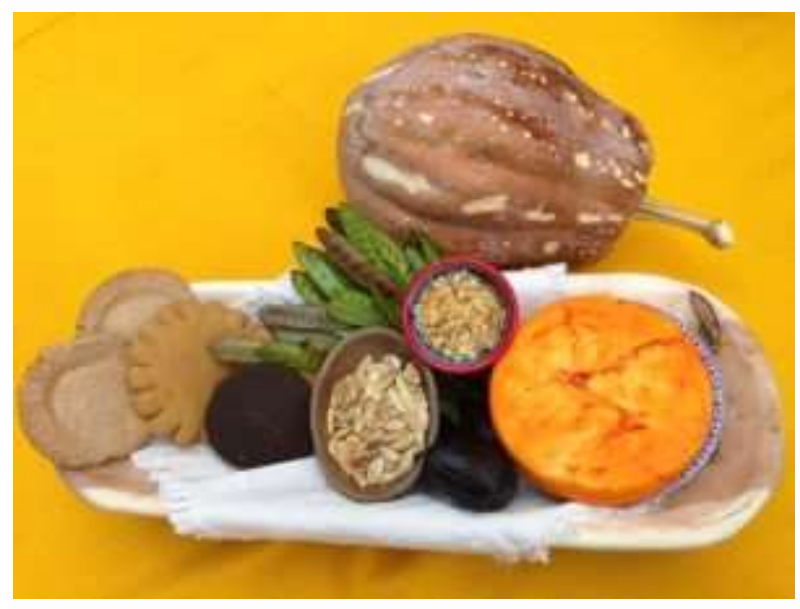

Figure 1 Cuachalalate

Juan Carlos Núñez

\section{Justification}

Ethnomedicine, ethnobotanical medicine, has presented us with a great impact that traditional medicine today is very effective as a preventive of scarring, deep wounds, since it has great effectiveness in traditional alternative medicine.

\section{Methodology}

The research was carried out by the longitudinal transversal method. In this, a random sample of 60 people in ages ranging from 50 to 70 years, both sexes, was considered. A questionnaire was applied through an open interview, which was supported by both qualitative and quantitative participatory research. It includes the following questions: 
1. How many times do you consume cuachalalate during the day?

2. What is the purpose of consuming the cuachalalate in water?

3. What type of diseases does cuachalalate treat?

4. Do you recommend the use of cuachalalate in people who have a wound or who have undergone surgeries to accelerate the healing process'?

5. What other plants do you use to prevent and cure diseases?

\section{Results}

Among the results obtained in the sample considered and that refer to the question about the daytime consumption of cuachalalate, the following was found:

\begin{tabular}{|l|r|r|}
\hline $\begin{array}{c}\text { Consumption } \\
\text { during the day }\end{array}$ & \multicolumn{1}{c}{$\begin{array}{c}\text { Number } \\
\text { of people }\end{array}$} \\
\hline 1 time & 3 & of people who use it daily \\
\hline 2 times & 5 & 5,00 \\
\hline 3 times & 48 & 8,33 \\
\hline $\begin{array}{l}\text { More than } 3 \\
\text { times }\end{array}$ & 4 & 80,00 \\
\hline Total & 60 & 6,67 \\
\hline
\end{tabular}

Table 1

$\%$ of cuachalalate consumption during the day

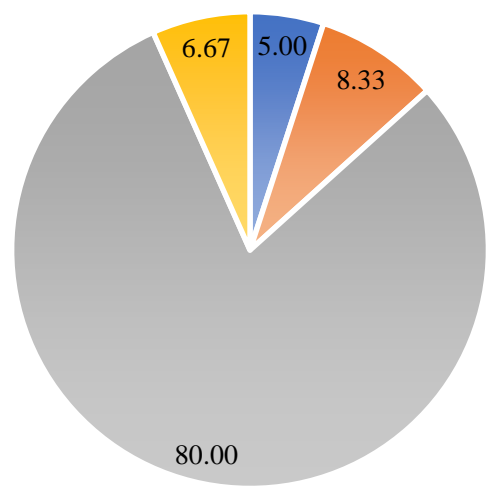

Graph 1

In the graph it can be seen that $80 \%$ of people who consume it do so 3 times a day, which suggests that its consumption is like water for use. It is important to mention that the people interviewed suggest its use in a preventive and curative way. They name its use for wound healing and preventing cancer.
Of the total of individuals with whom they spoke, $28.33 \%$ mention making use of cuachalalate in a preventive way, while $71.66 \%$ do it to cure.

\begin{tabular}{|l|r|r|}
\hline & Number of people & \% of use \\
\hline Preventive use & 17 & 28,33 \\
\hline Curative use & 43 & 71,67 \\
\hline Total & 60 & 100 \\
\hline
\end{tabular}

Table 2

In the following graph it can be seen that 43 people of the total that make up the sample, use this medicinal plant to heal.

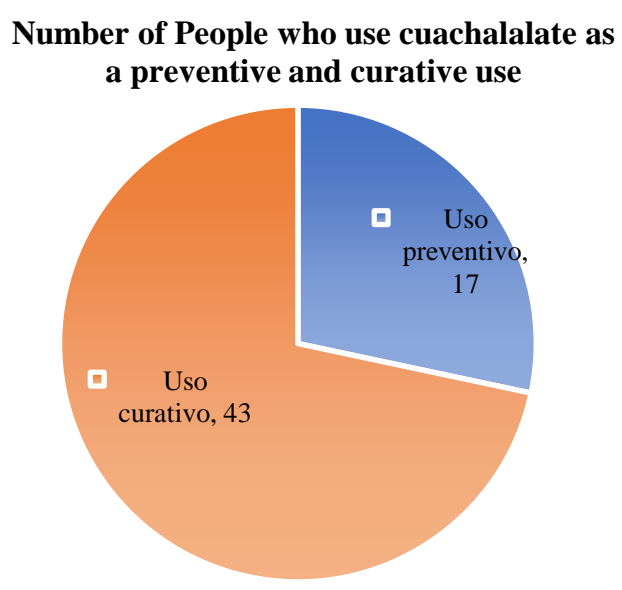

Graph 2

Among the diseases that are treated with cuachalalate, gastritis, preventing cancer, wound healing, stomach, etc. are mentioned.

\begin{tabular}{|l|r|r|}
\multicolumn{1}{|c|}{ Diseases } & Number of people & \% use in diseases \\
\hline Gastritis & 8 & 13,33 \\
\hline Prevent Cancer & 2 & 3,33 \\
\hline Wound Healing & 45 & 75,00 \\
\hline Stomach & 5 & 8,33 \\
\hline Total & 60 & 100 \\
\hline
\end{tabular}

Table 3

Of these diseases, the majority number is represented by wound healing, with 45 people from the total sample. This implies $75 \%$, which can be seen in the following graph. 
Diseases for which cuachalalate uses, \%

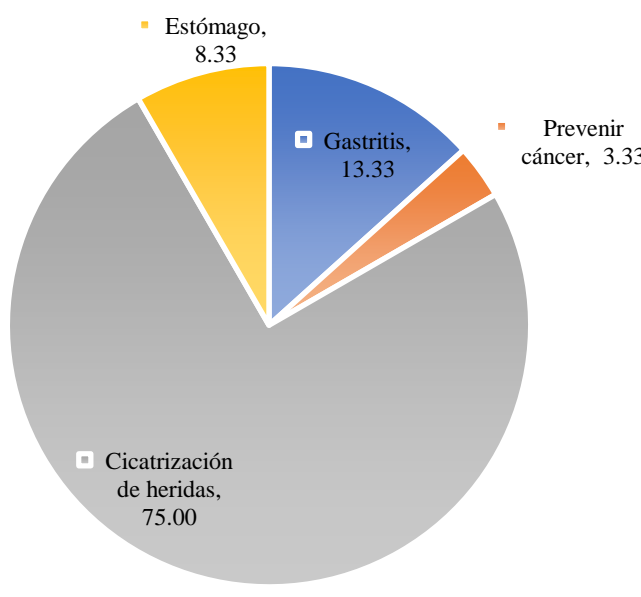

Graph 3

It can also be perceived that only $3.33 \%$ use it to prevent some type of cancer, so its impact lies in the healing of wounds. The foregoing encourages us to ask, then, if its use is recommended after surgery to accelerate the healing process or in minor wounds.

For this, 42 interviewees indicate that they do recommend it. This is represented by $70 \%$ of the sample.

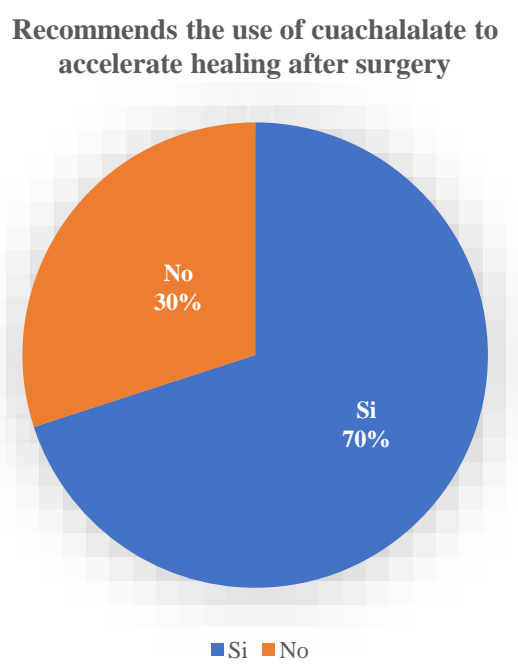

Graph 4

It is important to mention that they also consider other types of plants to prevent and cure diseases, within these are mentioned:

\begin{tabular}{|l|r|r|}
\hline \multicolumn{1}{|c|}{ Plant } & Persons & \% people who use it \\
\hline Temachaca & 15 & 25,00 \\
\hline Lick yourself & 3 & 5,00 \\
\hline Oregano & 8 & 13,33 \\
\hline Random & 7 & 11,67 \\
\hline Moringa & 2 & 3,33 \\
\hline Grade blood & 18 & 30,00 \\
\hline Mullein & 7 & 11,67 \\
\hline Total & 60 & 100 \\
\hline
\end{tabular}

Table 3

plants used to prevent and treat diseases, $\%$

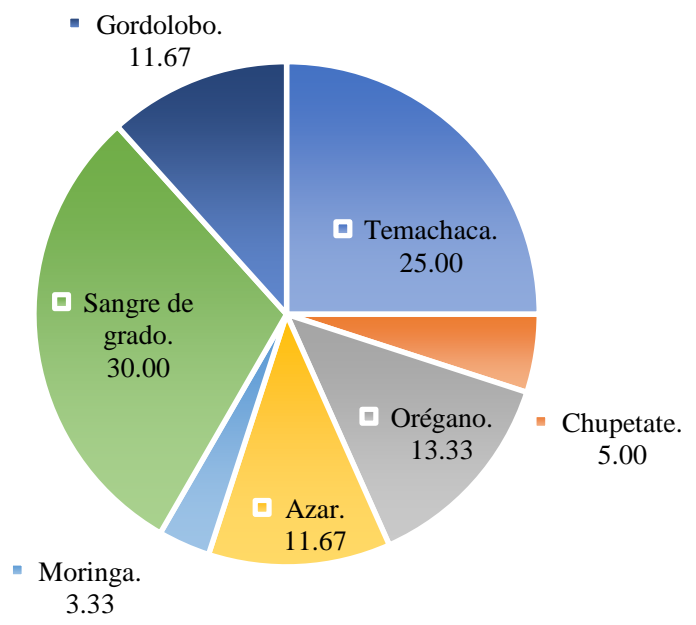

Graph 5

Apart from the cuachalate, they consider the blood of the grade and the temachaca as plants of use.

\section{Conclusions}

The bark of the cuachalalate that is commercialized in Mexico, is mainly collected in the municipality of Mezquitic, Jalisco.

\section{Acknowledgments}

A thank you to the authorities of the Municipality of Mezquitic Jalisco Zacatecas

\section{References}

Caldentey, P. 1986. Comercialización de productos agrarios. Editorial Agrícola Española. Madrid, España. 199p.

Mendoza, G. 1987. Compendio de mercadeo de productos agropecuarios. Instituto Interamericano de Cooperación para la Agricultura. San José Costa Rica, Costa Rica. $343 \mathrm{p}$. 
Olivera O., A. G., M. Soto H., M. Martínez V., T. Terrazas S. y F. Solares A. 1999. Phytochemical study of Cuachalalate (Amphipterygium adstringens, Schiede ex Schlecht.) Elsevier Science Ireland. Journal of Ethnopharmacology 68 :109-113.

Solares A., F. 1999. Estudio Químico-Biológico para una producción sostenida de corteza de cuachalalate para uso farmacéutico-industrial en el estado de Morelos. Informe Técnico. INIFAPSAGARPA. Campo Experimental Zacatepec. Zacatepec, Morelos. 37p.

Solares A., F. y Ma. C. Gálvez C. 2002. Diagnóstico biofísico y socioeconómico de las Áreas Naturales Protegidas de jurisdicción estatal en Morelos. CD1.INIFAP-CEAMAMorelos. Morelos, México.168p.

Solares A., F. y Ma. C. Gálvez C. 2002. Manual para una producción sustentable de corteza de Cuachalalate (Amphipterygium adstringens Schiede ex Schlecht.). Publicación especial No. 34. INIFAP-SAGARPA. Campo Experimental "Zacatepec". Zacatepec, Mor. México. 15 p.

Solares A., F., J. Jasso M., J. Vargas H., M. Soto H. y C. Rodríguez F. 2006. Capacidad de regeneración en grosor y lateral en corteza de cuachalalate (Amphipterygium adstringens Schiede ex Schlecht) en el estado de Morelos. RA XIMHAI. 2:481-495.

Solares A., F. 2007. Alineación de la investigación para la conservación y aprovechamiento sustentable del cuachalalate (Amphipterygium adstringens Schiede ex Schlecht.). Informe Técnico. INIFAPSAGARPA. Campo Experimental "Zacatepec". Zacatepec, Mor. México. 30 p.

Solares A., F. 2009. Aprovechamiento sustentable de cuachalalate (Amphipterygium adstringens Schiede ex Schlecht.) bajo un marco legal: Tecnología INIFAP. In: Memoria. IV Reunión Nacional de Innovación Agrícola y Forestal. Saltillo, Coah. México. pp 315. 